\title{
Studies on "Mesophase"-Pitch-Based Carbon Fibers, Part III. Intercalation of Sulfuric Acid
}

\author{
Norio Iwashita and Michio Inagaki
}

(Received March 27, 1991)

\author{
Department of Applied Chemistry, \\ Faculty of Engineering, Hokkaido University, \\ Kita-ku, Sapporo, Hokkaido 060, Japan
}

\begin{abstract}
Four kinds of "mesophase"-pitch-based carbon fibers with different textures in their cross-sections were used as host materials for graphite intercalation compounds with sulfuric acid. Sulfuric acid could intercalate into only fibers having positive value of magnetoresistance by chemical oxidation with nitric acid. This seemed to be a criterion for the intercalation. The potential change during the intercalation was found to depend on texture of fibers; the ones with radial texture increasing their potentials rapidly, probably due to their large edge surface area of graphite structure, and the ones with concentric texture showing stepwise increase of potential, almost the same as the case of flaky natural graphite powder with a large particle size.
\end{abstract}

KEYWORDS: Carbon fiber, Graphite intercalation compound, Sulfuric acid, Potential change, Chemical oxidation, Texture.

\section{Introduction}

The graphitization degree and the texture of host graphite materials have been shown to give a strong influence on intercalation reaction. A remarkable effect of host graphite during electrochemical intercalation of sulfuric acid was shown by using different carbon materials. ${ }^{1,2}$ ) However, there has been no investigation for effect of texture of host material on intercalation behavior.

Potential of graphite during the intercalation of sulfuric acid into flaky natural graphite powder by chemical oxidation was found to increase stepwise and to be able to follow the intercalation process. ${ }^{3,4}$ ) A typical curve of potential change with reaction time is shown in Fig. 1. By comparing this potential change with that observed during electrochemical oxidation, the intercalation of sulfuric acid into graphite by chemical oxidation was concluded to be fundamentally the same process as the electrochemical one; potential of graphite increases and intercalation of sulfuric acid proceeds. The intercalation process was reported from the potential changes electrochemically observed to consist of two elemental processes; ${ }^{5,6)}$ the increase in potential corresponding to charging of the graphite layers and the potential plateau to the transformation of stage structure in the gallery of graphite, as indicated in Fig. 1. The potential changes with chemical oxidation of graphite to $\mathrm{H}_{2} \mathrm{SO}_{4}$-GICs, therefore, could be explained by these two elemental processes. ${ }^{3,4)}$ Thus, the intercalation behavior into graphite by chemical oxidation can be followed in situ by measuring the potential. 


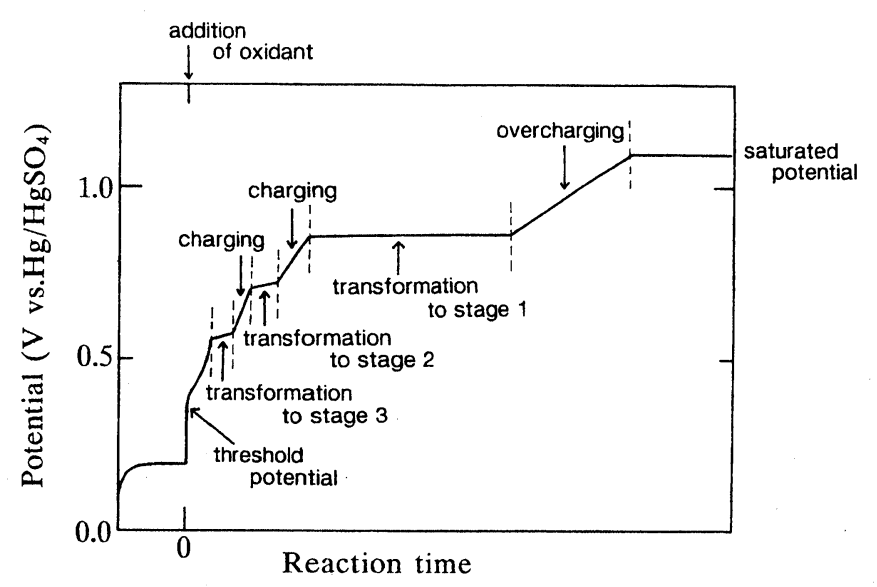

Fig. 1 Potential change of flaky natural graphite powder with average size of $400 \mu \mathrm{m}$ during intercalation of sulfuric acid by chemical oxidation.

Previously, four kinds of "mesophase"-pitchbased carbon fibers with different textures have been studied in order to understand the dependence of their structural development and properties on their textures. ${ }^{7,8)}$ In the present work, the same fibers were used as host materials for graphite intercalation compounds with sulfuric acid $\left(\mathrm{H}_{2} \mathrm{SO}_{4}-\mathrm{GICs}\right)$. The dependence of intercalation behavior on texture and electronic properties of host materials was discussed on the basis of the measurements of potential changes during intercalation of sulfuric acid by chemical oxidation.

\section{Experimental}

Data on heat-treatment temperature (HTT), texture in cross-section, lattice parameters determined by X-ray powder diffraction, and magnetoresistance for the host fibers are summarized in Table 1. Textures of the fibers were studied on their fractured surface with a highfidelity scanning electron microscope. Lattice parameters, average interlayer spacing $d_{002}$ and crystallite sizes $L_{\mathrm{C}}(004)$ and $L_{\mathrm{a}}(110)$, were determined by referring to the inner standard of silicon and by using Ni-filtered $\mathrm{Cu} \mathrm{K} \alpha$ radiation. Probability $P_{1}$ of neighboring layers having the graphitic relation (i.e. the degree of graphitiza- tion) was calculated from the profile of 11 diffraction line ${ }^{9)}$. The crystallite magnetroresistance, $(\Delta \rho / \rho)_{\mathrm{cr}}$, was measured at liquid nitrogen temperature under the magnetic field of $1 \mathrm{~T} .{ }^{10}$ ) The details of the characterization on the present fibers were reported previously. ${ }^{7)}$

A bundle of carbon fibers with the length of $10 \mathrm{~mm}$ (50 mg in weight) was held between two plastic plates with platinum wire as a supporting electrode. The electrode of $\mathrm{Hg} / \mathrm{HgSO}_{4}$ with Luggin capillary was adopted as a reference. Potential change of the carbon fiber electrode after addition of nitric acid (13.8 $\left.\mathrm{mol} / \mathrm{dm}^{3}\right)$ into sulfuric acid $\left(18 \mathrm{~mol} / \mathrm{dm}^{3}\right)$ of $50 \mathrm{~cm}^{3}$ was continuously recorded. The molar ratio of $\mathrm{HNO}_{3}$ to carbon was kept at a constant, 3.3, in all experiments. The test cell was covered with a plastic film to prevent absorption of moisture in air by sulfuric acid and also kept at constant temperature of $0{ }^{\circ} \mathrm{C}$ by using a bath with an ice-water mixture. The sulfuric acid solutions were bubbled by nitrogen gas and also magnetically stirred.

The stage structure of $\mathrm{H}_{2} \mathrm{SO}_{4}$-GICs was determined from X-ray powder pattern measured at room temperature by preventing the decomposition in a polyethylene bag with nitrogen atmosphere. 
Table 1 Data on heat-treatment temperature (HTT), texture, lattice parameters and magnetoresistance of the "mesophase"-pitchbased carbon fibers used.

\begin{tabular}{cccccccr}
\hline $\begin{array}{c}\text { sample } \\
\text { code }\end{array}$ & $\begin{array}{c}\mathrm{HTT} \\
{\left[{ }^{\circ} \mathrm{C}\right]}\end{array}$ & texture & $\begin{array}{c}d_{002} \\
{[\mathrm{~nm}]}\end{array}$ & $\begin{array}{c}L_{\mathrm{c}}(004) \\
{[\mathrm{nm}]}\end{array}$ & $\begin{array}{c}L_{a}(110) \\
{[\mathrm{nm}]}\end{array}$ & $P_{1}$ & $\begin{array}{c}(\Delta \rho / \rho)_{\mathrm{cr}} \\
{[\%]}\end{array}$ \\
\hline I-1-28 & 2800 & radial & 0.3371 & 18 & 64 & 0.36 & 2.992 \\
I-1-30 & 3000 & with wedge & 0.3368 & 32 & 81 & 0.41 & 12,447 \\
I-2-28 & 2800 & radial & 0.3401 & 9 & 20 & 0.25 & -1.455 \\
I-2-30 & 3000 & & 0.3385 & 12 & 40 & 0.30 & 0.372 \\
I-3-26 & 2600 & doubly- & 0.3395 & 10 & 23 & 0.28 & -1.150 \\
I-3-30 & 3000 & textured & 0.3380 & 13 & 45 & 0.32 & 0.849 \\
I-4-26 & 2600 & concentric & 0.3392 & 10 & 29 & 0.26 & -1.083 \\
I-4-30 & 3000 & & 0.3379 & 14 & 56 & 0.35 & 0.352 \\
\hline
\end{tabular}

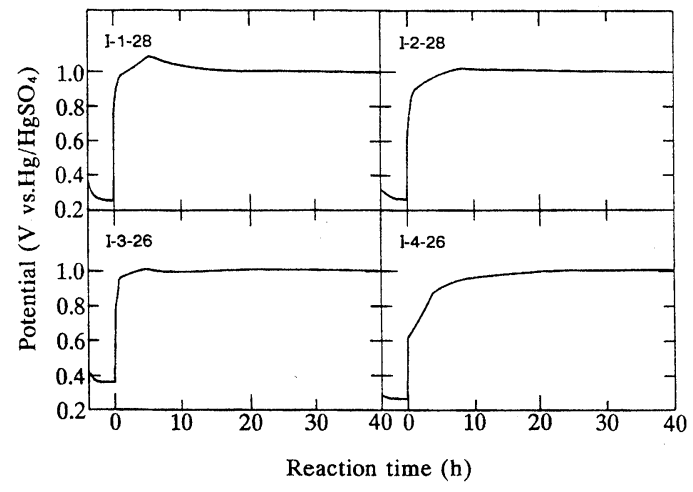

(a)

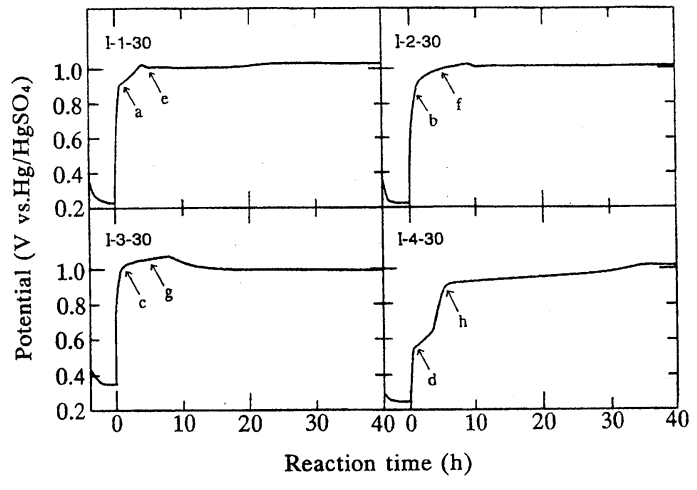

(b)

Fig. 2 Potential changes of the "mesophase"-pitch-based carbon fibers with reaction time during chemical oxidation in sulfuric acid; (a) carbon fibers with low HTT, (b) carbon fibers heat-treated at $3000^{\circ} \mathrm{C}$.

\section{Results}

The potential changes with reaction time during intercalation of sulfuric acid by chemical oxidation are shown in Fig. 2. In these figures, the reaction time is counted from the moment when the oxidant $\mathrm{HNO}_{3}$ is added. X-ray powder patterns of each sample oxidized for 40 hours, when the potential is saturated, are shown in Fig. 3.

Four kinds of fibers heat-treated at $3000^{\circ} \mathrm{C}$ are transformed to the stage- 1 compounds, after the potential is saturated at 40 hours (Fig. 3 (b)). All diffraction lines observed are indexed by using the identity period along the c-axis, $d_{\dot{1}}$, of $0.80 \mathrm{~nm}$. The fiber I-1-28, which has a radial texture with open wedge, is also allowed to be intercalated by sulfuric acid and transformed to the stage- 1 compound, as shown in Fig. 3 (a). In the fibers I-2-28, I-3-26 and I-4-26 which have negative values of magnetoresistance (Table 1), however, no diffraction lines due to the intercalation compounds are detected on these powder patterns (Fig. 3 (a)) even after the oxidation for 40 hours, suggesting no intercalation of sulfuric acid into these fibers.

Regardless of HTT, potentials of three kinds of host fibers (I-1, I-2 and I-3 fibers) increase 
1991 [No. 149] Studies on "Mesophase"-Pitch-Based Carbon Fibers, Part Ill . Intercalation of Sulfuric Acid

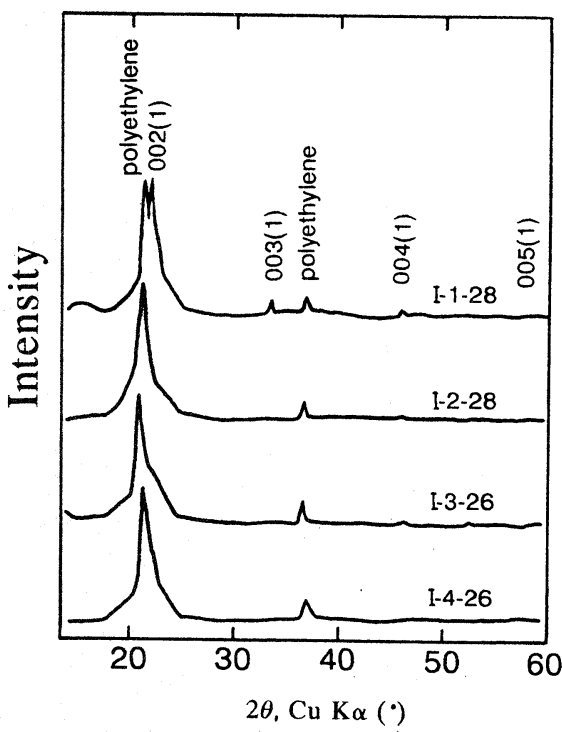

(a)

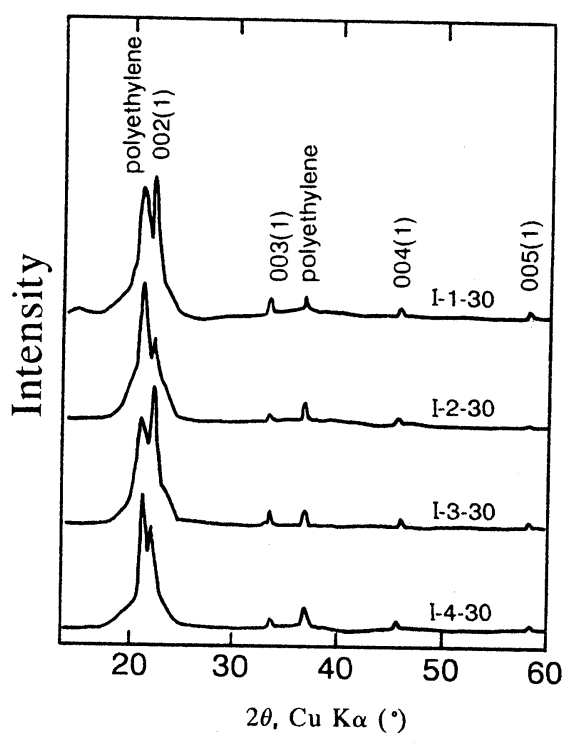

(b)

Fig. 3 X-ray powder patterns of the carbon fibers oxidized in sulfuric acid for 40 hours; (a) carbon fibers with low HTT, (b) carbon fibers heat-treated at $3000^{\circ} \mathrm{C}$.

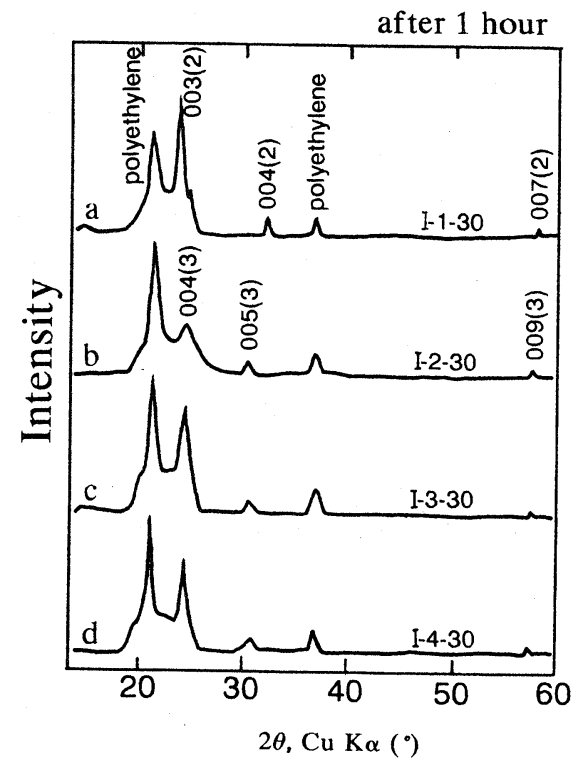

(a)

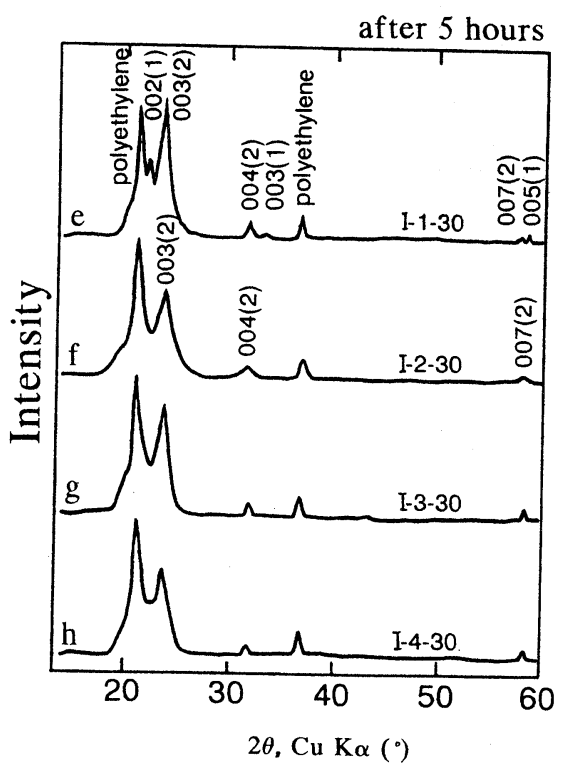

(b)

Fig. 4 X-ray powder patterns of the carbon fibers oxidized in sulfuric acid; (a) after 1 hour, (b) after 5 hours. 
rapidly up to around $0.9 \mathrm{~V}$ and then gradually increase. On the fibers I-1-28, I-1-30, I-2-30 and I-3-30, a "over-shot" phenomenon is observed; once the potential increases beyond the saturated potential and then decreases to around $1.05 \mathrm{~V}$. The fiber I-4-30 having concentric texture, in contrast, does not show any over-shot phenomenon and gives a stepwise potential change, two distinct plateaux at 0.6 and $0.9 \mathrm{~V}$. The same series of fiber heat-treated at low temperature (I-4-26) does not show any distinct plateau but no over-shot phenomenon on its potential change.

$\mathrm{X}$-ray powder patterns of the $3000{ }^{\circ} \mathrm{C}$-treated fibers oxidized in sulfuric acid for 1 and 5 hours, corresponding to the points from $\mathbf{a}$ to $\mathbf{h}$ on the potential changes in Fig. 2 (b), are shown in Fig. $\mathbf{4 a}-\mathbf{h}$, respectively. The intercalation of sulfuric acid into the fiber I-1-30, which has the highest degree of graphitization $\left(P_{1}=0.41\right)$ among the present fibers, proceeds with the fastest speed; the stage- 2 compound $\left(d_{\mathrm{i}}=1.14\right.$ $\mathrm{nm}$ ) being obtained even after 1 hour reaction and a mixture of the stage- 2 and -1 structures after 5 hours. In the other three fibers, the stage-3 $\left(d_{\mathrm{i}}=1.47 \mathrm{~nm}\right)$ and -2 compounds are observed after 1 and 5 hours, respectively. Two potential plateaux at 0.6 and $0.9 \mathrm{~V}$ observed in the fiber I-4-30 correspond to the transformation to the stage- 3 from higher stage structures and to the stage- 1 from the stage- 2 structures, respectively.

\section{Discussion}

In the present fibers, two regions with different textures in micrometric scale, microporous non-graphitic (turbostratic) and graphitic regions, were observed by high-resolution transmission electron microscopy (TEM), ${ }^{7)}$ even though they were heat-treated at high temperatures. This non-graphitic region was supposed to be responsible for low values of graphitization degree $\left(P_{1}<\right.$ $0.5)$. The magnetoresistance, $(\Delta \rho / \rho)_{\mathrm{cr}}$, measured at liquid nitrogen temperature is positive for graphitic but negative for turbostratic structure, ${ }^{10)}$ and has been shown to be a measure of graphitization degree. The negative and small

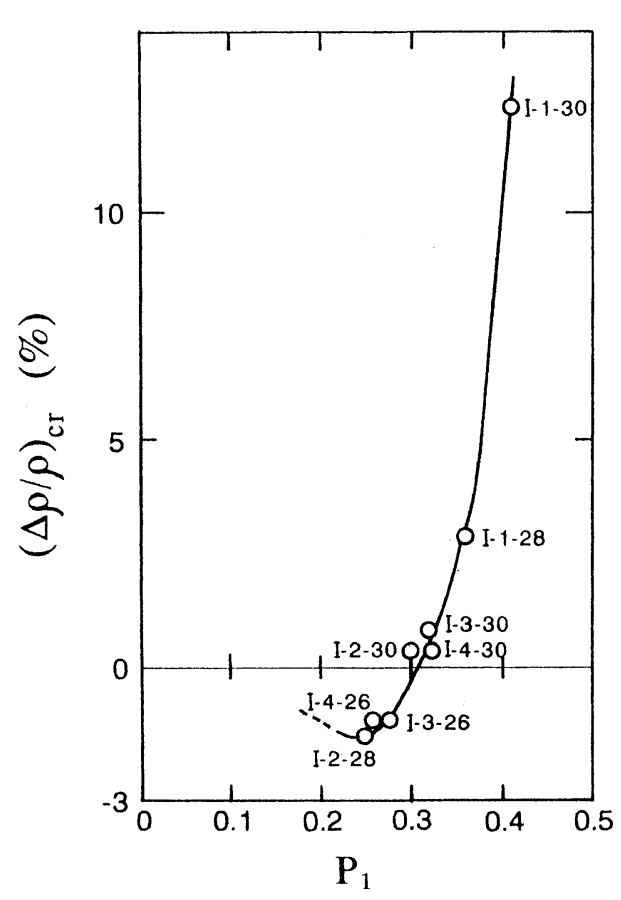

Fig. 5 Crystallite magnetoresistance $(\Delta \rho / \rho)_{\mathrm{cr}}$ against graphitization degree $P_{1}$ of the "mesophase"-pitch-based carbon fibers. heat-treated at high temperatures.

positive values of $(\Delta \rho / \rho)_{\mathrm{cr}}$ for the present fibers heat-treated even up to $2800^{\circ} \mathrm{C}$ are due to the existence of non-graphitic regions.

In Fig. 5, magnetoresistance $(\Delta \rho / \rho)_{\mathrm{cr}}$ is plotted against graphitization degree $P_{1}$ for the present fibers with their codes. There can be a unique relationship and so a line is drawn by taking account of the fact that the magnetoresistance value has a minimum in negative region. ${ }^{10)}$ At the $P_{1}$-values of around 0.3 , the magnetoresistance value changes its sign from negative to positive. The reason why the transition in magnetoresistance from negative to positive values locates around $P_{1}$ of 0.3 , not at 0.5 , is not clear yet.

It is worth while to mention two points on the basis of the present results on intercalation behaviors of sulfuric acid into the carbon fibers; a fiber having positive magnetoresistance can be converted to intercalation compounds and a strong effect of fiber texture on intercalation 
behavior is observed.

In relation to the first point, this is the first time to give a criterion for the intercalation of sulfuric acid. For acceptor-type intercalates, for instance sulfuric acid, bromine and metal halides, rather limited host materials such as natural graphite and HOPG have been used. Only a few works on the electrochemical intercalation of sulfuric acid ${ }^{1), 2)}$ were performed by using the host with wide range of structure, but there was no discussion on the criterion of host structures. Although still more studies have to be done, the present result strongly suggest that the characterization of hosts based on electronic properties, such as magnetoresistance, helps the understanding of intercalation behaviors.

For a curve of potential against reaction time during the intercalation, the slope gives a measure of the oxidation rate of graphite, in the other words, the rate of charging process of graphite layers. The charging process by chemical oxidation is reasonably supposed to proceed preferentially through edge surface of graphite structure. The fibers in I-1 and I-2 series have a radial texture in micrometric scale. The texture of the fibers in I-3 series is classified as doubly-textured, because of a little difference between the center and edge regions ${ }^{7)}$, but the fundamental arrangement of layers in the crosssection is radial. In these three series of fibers, therefore, the edge surface of graphite layers are reasonably supposed to be exposed to the sulfuric acid solution with oxidant in higher possibility than in the fiber series I-4 having concentric texture. This is the reason why the potential increases so rapidly. Probably as a consequence of this rapid increase, no plateaux corresponding to stage transformation and even over-shot phenomenon are observed in the fibers with radial texture. Even though no potential plateaux, the stage transformation was detected on X-ray powder patterns of these fibers, as shown in Fig. 4.

The charging process in the fiber I-4-30 was relatively slow probably because of its concentric texture, so that potential plateaux corresponding to the transformation to the stage- 3 and the stage- 1 compounds were observed at around 0.6 and $0.9 \mathrm{~V}$, respectively.

These experimental results suggest that the overall intercalation reaction of sulfuric acid into various host graphite materials seems to be governed by the relation in the rates between the charging and stage transformation processes.

\section{Conclusive Remarks}

The present results lead to the two following important points. 1) The host must have certain degree of graphitization to form graphite intercalation compound with sulfuric acid. The criterion for intercalation by chemical oxidation was to have a positive magnetoresistance. 2) The potential change during the intercalation by chemical oxidation depends strongly on texture of the host. The charging process of graphite layers corresponding to increase in potential is influenced on area of the edge surface of graphite structure. The potential change on different host materials seems to be explained on the basis of the competition of rates between the charging and stage transformation processes.

In a previous paper ${ }^{11}$, we reported the potential changes during electrochemical deintercalation of sulfuric acid from its GIC synthesized by chemical oxidation. Much larger electric quantity for electrochemical deintercalation (discharging) was needed than expected. The result was explained on the basis of the competition between chemical oxidation and electrochemical reduction in the electrolyte containing oxidant $\mathrm{HNO}_{3}$. The electrochemical de-intercalation process of $\mathrm{H}_{2} \mathrm{SO}_{4}$-GICs must depend on texture of the host graphite, as strongly as in the intercalation process. More detailed studies on the effect of texture as well as structure of the host graphite are necessary to understand fundamental intercalation behaviors of various graphite materials and also to develop their applications. 


\section{Acknowledgement}

This work was partly supported by the Grant for International Joint Research Project from the NEDO, Japan.

\section{References}

1) D. Horn and H.P. Boehm, Z. anorg. allg. Chem. 456, 117 (1979).

2) Y. Maeda, Y. Okemoto and M. Inagaki, J. Electrochem. Soc. 132, 2369 (1985).

3) M. Inagaki, N. Iwashita and E. Kouno, Carbon 28, 49 (1990).

4) N. Iwashita and M. Inagaki, Synth. Met. 34, 139 (1989).

5) A. Metrot, Synth. Met. 7, 177 (1983).
6) A. Metrot and M. Tihli, Synth. Met. 12, 517 (1985).

7) M. Inagaki, N. Iwashita, Y. Hishiyama, Y. Kaburagi, A. Yoshida A. Oberlin, K. Lafdi, A. Bonnamy and Y. Yamada, Tanso 1991 [No. 147] 57

8) Y. Tanabe, E. Yasuda, M. Inagaki and Y. Yamada, Tanso 1991 [No. 147] 66

9) M. Inagaki, M. Shiraishi, M. Nakamizo and Y. Hishiyama, Tanso 1984 [No. 118] 165

10) Y. Hishiyama, Y. Kaburagi and M. Inagaki, "Chemistry and Physics of Carbon", Vol. 23, Marcel Dekker, Inc. (1991) pp.2-68.

11) N. Iwashita and M. Inagaki, Tanso 1990 [No. 145] 228.

\section{学振 117 委員会第 215 回提出資料}

学振 117 委員会第 215 回会議が平成 3 年 7 月12日(金), 13日（土）に主婦会館に打いて開催された。各分科会には 下記の資料が提出され，活発な討論が成された。

117-215-A-1フッ素ガスを用いた炭素繊維の表面改 質（II）一表面特性之複合材料一 ((財)応用科学研) 鄭 容宝 ほか

117-215-A-2 無機多孔体を鋳型とした高分子化合物 の炭素化

（東北大反応研）永井隆行 ほか

117-215-B-1 溶融 KF・2HF に扔けるフッ素の電気 化学的インターカレーション

(京大工) 中島 剛 ほか

117-215-B-2 各種炭素繊維を用いたリチウム二次電 池（信州大）遠藤守信 ほか

117-215-C-1コイル状セラミック繊維

（長崎大）岩永 浩 ほ加

117-215-C-2 炭素/ $\mathrm{B}_{4} \mathrm{C} / \mathrm{SiC}$ 複合材料の酸化に及ぼ す雾囲気と温度の影響

（長崎大）前田和敏 ほか
117-215-C-3平滑な光沢平面をもつ CFRC の調整 （群馬高専）小島 昭 ほか

117-215-C-4 Evaluation of Thermal Stresses and Thermal Shock Resistances of Graphites for Use in Rocket Nozzle （茨城大）佐藤千之助 ほか

117-215-C-5 かたさ試験による炭素材料の強度評価

$117-215-\mathrm{C}-6$ 高温ガス炉用黒鉛の衝撃引張り強度特 性原研) 宇賀地弘和 ほか

117-215-C-7 原子炉級黒鉛材料の強度と欠陥に関す る研究 (原研) 石原正博 ほか

この他 “New Breakthroughs of Carbon Science" $\sim$ Discoveries and Physical Properties of $\mathrm{C}_{60}$ and $\mathrm{C}_{70}$, Magic Number FULLERENES

と題して, 日立製作所エネルギー研究所 小沢国夫氏の 講演があった。 